\title{
Structural and functional characteristics of algal flora in water bodies of the natural monuments in Orenburg forest steppe Trans Volga region (Russia)
}

\author{
Marina E. Ignatenko ${ }^{1}$, Tatyana N. Yatsenko-Stepanova ${ }^{1}$, and Olga $G$. Kalmykova ${ }^{2 *}$ \\ ${ }^{1}$ Institute for Cellular and Intracellular Symbiosis, Orenburg Federal Research Center, 460000, \\ Orenburg, Russia \\ ${ }^{2}$ Steppe Institute, Orenburg Federal Research Center, 460000, Orenburg, Russia
}

\begin{abstract}
The algal flora of 7 water bodies of Orenburg forest-steppe Trans Volga region protected areas was studied. 193 species and intraspecific taxa of algae belonging to 7 phyla, 12 classes, 30 orders, 57 families and 109 genera were identified. According to the results of a saprobiological analysis studied water bodies and streams are characterized as xeno-, oligo-, and $\beta$-mesosaprobic, grades 1-3 of quality, from extremely pure to satisfactory purity. In some water bodies (pond on the Zhmakovsky creek - natural monument «Kuzminka creek with tributaries» and pond of the natural monument «Aksakov's park»), disturbances in the stability of ecosystems and various stages of eutrophication were recorded. The data obtained indicate the need for strict compliance with the restrictions already provided for these natural monuments and the use of more effective protection measures to restore ecosystems and improve water quality within the studied objects.
\end{abstract}

To date, 333 protected natural areas of regional significance (330 natural monuments and 3 reserves) have been allocated in the Orenburg region. Many of these include water bodies, which play a special role in steppe and forest-steppe zones. They form the nucleus of biodiversity concentration in general and particularly floristic diversity. Algae are a significant component of aquatic ecosystems. The structural and functional characteristics of algal flora allow conclusions to be drawn on the state and functioning of aquatic ecosystems, water productivity, water quality. This is the criterion for assessing the ecological status of water bodies [1-4]. This makes it important to study the taxonomic composition and the quantitative development of the algal flora of these areas.

The subject of this study was qualitative and quantitative water samples taken from water bodies and watercourses located on the territory of 6 natural monuments of regional significance during the summer of 2018 (fig. 1).

Natural monument of regional significance «Nizhniy Kurmey cliff» (geological specialty). Subject of study - Kurmeika River (53.534192 N, 53.930133 E) (fig. 1).

* Corresponding author:okstepposa@gmail.com 
Kurmeyka River (left-bank tributary of the Karatay-SadakRiver) belongs to the Kama Basin District and has a length of $19 \mathrm{~km}$. The river is fed by spring and meltwater. Salix (Salix alba L., S. cinerea L. et al.) is common on the banks of the watercourse at the sampling point (discharge of groundwater). The meadow plant communities are developed along the riverbed. Vegetation is susceptible to overgrazing.

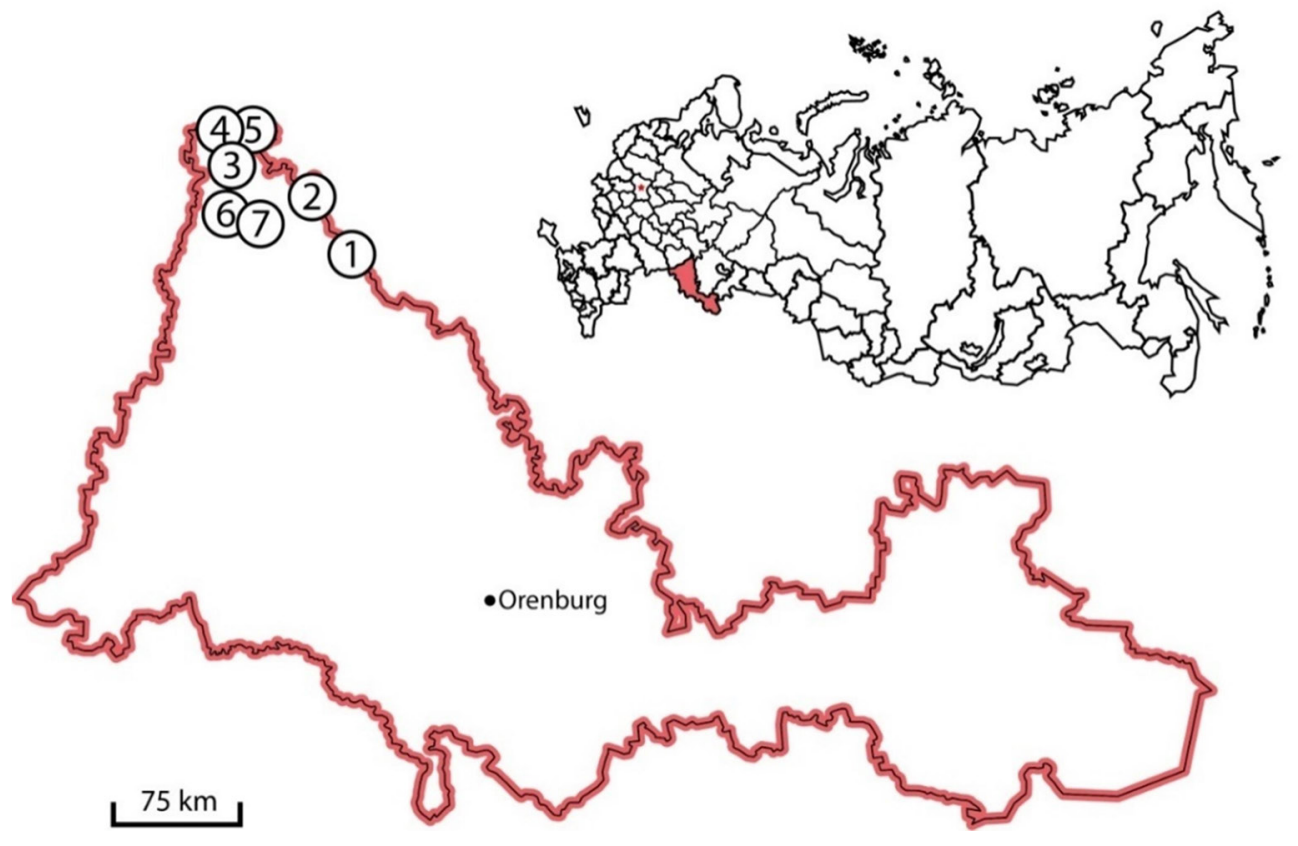

Fig. 1. The location of the studied water bodies. Note : 1 - Kurmeyka River, natural monument «Nizhniy Kurmey cliff»; 2- Rodnikovka River, natural monument «Hanging Springs of Rodnikovka»; 3- Secretarka River, natural monument «Gully and spring Lei Latka (Straight gully)»; 4- KuzminkaCreek, natural monument «KuzminkaCreek with tributaries»; 5 - pond on the ZhmakovskyCreek, natural monument «KuzminkaCreek with tributaries»; 6 - pond, natural monument «Aksakov's park»; 7 - spring, natural monument «Plantings by the A.N. Karamzin on the White Farm»

Natural monument of regional significance «Hanging Springs of Rodnikovka» (hydrological and geological specialty). Subject of study - Rodnikovka River (53.981697 $\mathrm{N}, 53.491675 \mathrm{E}$ ) (fig. 1). The mouth of the river is $470 \mathrm{~km}$ on the left bank of the river Ik. Total length of the Rodnikovka River $16 \mathrm{~km}$, catchment area $62.9 \mathrm{~km} 2$. River belongs to the Kama Basin District. The river is fed by spring and meltwater. The vegetation near the river at the water sampling point has been significantly damaged by overgrazing. Tussilagofarfara L. is abundant along the riverbed and on the adjacent slope with spring exits. The vegetation on the bank is mosaic.

Natural monument of regional significance «Gully and spring Lei Latka (Straight gully)» (geological specialty). Subject of study - Secretarka River (54.140539 N, 52.824447 E) (fig. 1). The river is fed mainly by groundwater. The left bank of the watercourse is the slope of a gully with no vegetation cover, in places with little vegetation cover. The right bank is flat, occupied by disturbed meadows. The thickets of Urticadioica L. and U. dioica with Cicutavirosa L. are noted. Common are the large patches of Fragariaviridis (Duchesne) Weston and Carex praecoxSchreb. Closer to the riverbed are the disturbed meadows with domination of Bromopsisinermis (Leyss.) (Holub). Salix (Salix 
cinerea, $S$. pentandra L. et al.) and meadow plant communities are scattered near the riverbed. The water was sampled in the riverbed near the Lei Latka spring.

Natural monument of regional significance «KuzminkaCreek with tributaries» (hydrological and ichthyological specialty). Subject of study - KuzminkaCreek (54.271506 N, 52.790278 E) and pond on the ZhmakovskyCreek (54.268286 N, 52.819897 E) (fig. 1). Vegetation cover near the riverbed of the KuzminkaCreek is formed by forest communities with the participation of Salix spp., Padusavium Mill and Alnusincana (L.) Moench. Urticadioica is abundant in the grass-shredded layer. It is also common in the valley of the creek meadows mainly Brometuminermitisherbosum. Vegetation around the pond on the ZhmakovskyCreek is formed by forest communities with the participation of Betula pendula Roth, Salix spp., Padusavium, thickets of shrubs (Caraganafrutex(L.) C.Koch) and meadows.

Natural monument of regional significance «Aksakov's park» (landscape and historical specialty). Subject of study is a pond (53.865517 N, 52.632469 E) (fig. 1), created in 17621767 and restored in 1981-1990. Currently, the pond is drying up, rising along the banks of the Phragmiteaustralis (Cav.) Trin. ex Steudel and Typhalatifolia L.

Natural monument of regional significance «Plantings by the A.N. Karamzin on the White Farm» (silvicultural specialty). Subject of study - spring (53.694797 N, 52.896275 E), whose waters form a stream that flows through the territory of a natural monument. Along the riverbed there are Salix alba, S. cinerea, Acer nundo L, in the riverbed and coastal groups of the ScirpussylvaticusL., Veronica anagallis-aquaticaL., Tussilagofarfara, Persicariascabra (Moench) Moldenke. Mosaic, disturbed meadow plant communities are common, and the thickets of Urticadioica are noted.

Algal samples, fixation and treatment were carried out according to the generally accepted algological methods. Algae were identified according to determinants [5-8]. Taxonomy and nomenclature according to the on-line database Algaebase [9]. The PantleBukkaw index of the Sladechek modification was used to determine the saprobity of the waters [10]. The water quality class was established based on data presented in the works of S.S. Barinova $[1,2,11]$.

The algal flora of studied water bodies is represented by193 species and intraspecific taxa of algae belonging to 7 phyla, 12 classes, 30 orders, 57 families and 109 genera.

In Kurmeyka River73 taxa ranked below the genus were identified. They belong to 5 phyla: Bacillariophyta, Chlorophyta, Cyanobacteria, Euglenozoa, Charophyta. The largest species richness and quantitative development were diatoms (59 species ( $80.8 \%$ of total species composition) 30240 thousand $\mathrm{kl} / \mathrm{l}$ ( $99.6 \%$ of the total number). This may be due to the shallow depth of the watercourse and the introduction into the water column of bottom and periphytic forms of diatoms under the influence of the current. In general, the predominance of Bacillariophyta in the algal community is characteristic of most running water habitats $[4,12,13]$.

According to a saprobiological analysis, the watercourse is characterized as $\beta$ mesosaprobic $(S=1.96)$. According to the water quality assessment system for algal saprobity $[1,2,11]$ the water of the Kurmeyka River can be classified in class 3 of quality (satisfactory purity); water quality discharge - 3a (reasonably clean); the ecosystem crisis zone - self-purification to natural background.

In Rodnikovka River 38 taxa ranked below the genus were identified. They belong to 6 phyla: Bacillariophyta, Chlorophyta, Euglenozoa, Cyanobacteria, Charophyta, Ochrophyta. By species richness (25 species, $65.8 \%$ of total species composition) and quantitative development (67.2 thousand $\mathrm{kl} / \mathrm{l}$, which corresponds to $70.6 \%$ of total algal number), as in the Kurmeika River, are dominated by diatoms. However, there is also a high proportion of euglenids $(14.6 \%$ of the total) due to the growing of indicator species 
Monomorphinapyrum(Ehrenberg) Mereschkowsky (8.8\%) and Euglenaformisproxima (P.A.Dangeard) M.S.Bennett\&Triemer (5.9\%).

According to a saprobiological analysis, the Rodnikovka River is characterized as $\beta$ mesosaprobic $(\mathrm{S}=2.15)$. River waters can be classified in class 3 of quality (satisfactory purity); discharge of water quality - $3 \mathrm{~b}$ (slightly polluted); the ecosystem crisis zone threat.

The algal flora of the Secretarca River at the sampling point is exclusively represented by Bacillariophyta (16 taxa ranked below the genus) with a dominance of Planothidiumlanceolatum (BrébissonexKützing) Lange-Bertalot (53.1\% of the total number number). The inaccessibility and remoteness of the Sekretarka River from settlements and highways is beneficial to the condition of the watercourse.

The saprobity index was 1.25 , which corresponds to the oligosaprobic zone. The waters of the watercourse can be classified in class 2 as quality (pure); discharge of water quality $2 \mathrm{~b}$ (quite clean); the ecosystem crisis zone - natural and clean waters.

There are 42 species belong to 6 phyla (Bacillariophyta, Chlorophyta, Euglenozoa, Cyanobacteria, Charophyta) in algal flora of the KuzminkaCreek. Diatoms were the main contributors to the species richness and the number of algae in the watercourse, as in the running water habitats described above $(73.8 \%$ of the total species richness, $74.5 \%$ of the total number).

The saprobity index was 1.94 which made KuzminkaCreek appear to be $\beta$ mesosaprobic. Creek waters can be classified in class 3 of quality (satisfactory purity); water quality discharge - 3a (reasonably clean); the ecosystem crisis zone - self-purification to natural background.

The pond on the ZhmakovskyCreek is actively used as a recreation area, which is certainly reflected in the structure of the algal community. In the algal flora of the pond, 15 species of algae of rank below the genus, belonging to the phyla Bacillariophyta, Chlorophyta, Cyanobacteria, Euglenozoa, Ochrophyta have been identified. Of these, the largest number of species belonged to Bacillariophyta, but the contribution of diatoms to the total number algae community of the pond was low, at only $8 \%$. The dominant group was Chlorophyta $(66.7 \%$ of the total number of algae). At the same time, the share of Chlorococcum sp. in the community structure was $64.8 \%$. The predominance of monodominant communities in the algal flora structure indicates a disruption of ecosystem stability and the initial stage of eutrophication due to anthropogenic impacts $[3,14]$.

The saprobity index was 1.78 which made pond on the ZhmakovskyCreek appear to be $\beta$-mesosaprobic. Pond waters can be classified in class 3 of quality (satisfactory purity); water quality discharge - 3a (reasonably clean); the ecosystem crisis zone - self-purification to natural background.

The algal flora of the pond, located in «Aksakov's park», was distinguished by the highest indicators of qualitative and quantitative development compared to other studied water objects. Representatives of 7 algae phyla (Chlorophyta, Bacillariophyta, Cyanobacteria, Euglenozoa, Charophyta, Miozoa, Ochrophyta) were identified in the pond. Among them, Chlorophyta was the most diverse (36 taxa below the genus). However, Cyanobacteria dominated in quantitative terms, the number of which at the time of sampling was $98.4 \%$ of the total number of cells (151058.6 thousand $\mathrm{kl} / \mathrm{l}$ ). At the same time, mass vegetation of Merismopedia minimaG.Beck was registered $(70.1 \%$ of the total number), as well as significant development of Coelosphaeriumdubium Grunow (6.6\%), MerismopediatenuissimaLemmermann (4.8\%), Anagnostidinemaamphibium (C. AgardhexGomont) Strunecký, Bohunická, J.R.Johansen\&J.Komárek (3.9\%), Microcystisaeruginosa (Kützing) Kützing (3.0\%), Chroococcusminutus (Kützing) Nägeli (2.8\%), Microcystispulverea (H.C.Wood) Forti (2.0\%). 
The large numerical superiority of Cyanobacteria is a warning sign of accelerated eutrophication of the water body $[3,15]$. Also, given that Cyanobacteria is a source of a wide range of secondary metabolites, including toxins and enzyme inhibitors [16-18], their massive development poses a potential threat to animal and human health, using this pond as a source for water (animals, birds) or recreation zone (human).

At this stage, the pond in "Aksakov's Park» was characterized as $\beta$-mesosaprobic $(\mathrm{S}=1.94)$. Pond waters can be classified in class 3 of quality (satisfactory purity); water quality discharge - 3a (reasonably clean); the ecosystem crisis zone - self-purification to natural background.

The algal flora of the spring on natural monument «Plantings by the A.N. Karamzin on the White Farm»was characterized by the lowest species richness ( 7 species and intraspecies taxa). The algae found in the spring bowl belonged to the phylum Bacillariophyta.

The saprobity index was 0.39 , which characterizes the waters of the spring as xenosaprobic. The watercourse is classified in the 1 st class of quality (with maximum purity); the quality grade is 1 (with maximum purity); the ecosystem crisis zone is natural and clean water.

Thus, according to the results of the saprobiological analysis of the water bodies and watercourses of natural monuments in Orenburg forest-steppe Trans Volga are characterized as xeno-, oligo- and $\beta$ - mesosaprobic, 1-3 classes of quality, from maximum purity to satisfactory purity. Disturbances of ecosystem stability and different stages of eutrophication have been recorded in some water bodies (pond on the ZhmakovskyCreek, pond in «Aksakov's park»). The state of the Rodnikovka River (Natural monument of regional significance «Hanging Springs of Rodnikovka»), whose ecosystem is in the crisis zone - a threat, causes special alarm. The data obtained indicate the need for strict compliance with the restrictions already provided for these natural monuments and the use of more effective protection measures to restore ecosystems and improve water quality within the studied objects.

We gratitude to the staff of the Institute of steppe UB RAS P.V. Velmovsky and G.H. Dusaeva for assistance in field surveys.

\section{References}

1. S. Barinova, Int. J. of Env. Sc.\& Nat. Res., 2, e555581 (2017)

2. S. Barinova, Int. J. of Env. Sc.\& Nat. Res., 2, e555588 (2017)

3. E. A. Dembowska, T. Mieszczankin, P. Napiórkowski, Env. Monit. and Assessm, 190, 95 (2018)

4. S. Barinova, T. Smith, Diversity, 11, 206 (2019)

5. K. Krammer, H. Lange-Bertalot, Bacillariophyceae, 1-4 (Stuttgart, Jena: Gustav Fisher Verlag, 1986-1991)

6. J. Komárek, K. Anagnostidis, Cyanoprokaryota, 1-2 (München, Jena: Ficher Verlag, $1999-2005)$

7. M. S. Kulikovsky, A.M. Glushchenko, S.I. Genkal, I.V. Kuznetsov, Determinant of diatoms of Russia (Yaroslavl, Publishing House «Filigran», 2016)

8. P. M. Tsarenko, Brief determinant of chlorococcal algae of the Ukrainian SSR (Kiev, Publishing House «Naukova Dumka», 1990)

9. M. D. Guiry, G.M. Guiry, Algae Base, http://www.algaebase.org (2020)

10. V. Sládeček, Ergebnisse der Limnol., 7, 1-218 (1973) 
11. S. S. Barinova, L.A. Medvedeva, O.V. Anisimova, Biodiversity of algae-indicators of the environment (Tel-Aviv, Pilies Studi, 2006)

12. L. Yu. Khaliullina, Water: chem. and ecol., № 4-6, 55-62 (2018)

13. S. F. Komulainen, NCR, 3, 46-60 (2018)

14. T. M. Mikheeva, E.V. Lukyanova, Izv. of the Samara Sc. Cent. of the RAS, 8, 125-140 (2006)

15. T. Atici, C. Tokatli, Wulfenia, 21, 155-169 (2014)

16. J. G. Winter, A.M. De Sellas, R. Fletcher, L. Heintsch, A. Morley, L. Nakamoto, K. Utsumi, Lake and Res. Manag, 27, 107-114 (2011)

17. T. R. Miller, L.J. Beversdorf, C.A. Weirich, S.L. Bartlett, Marine Drugs, 15, 160 (2017)

18. A. S. Semenova, S.I. Sidelev, O.A. Dmitrieva, Biol. Bull., 44, 538-546 (2017) 